Annals of Tropical Research 32(2): 51-69 (2010)

\title{
Observations of Forestry Seedling Production Systems in Thailand and Vietnam
}

\author{
Steve Harrison $^{1}$ and Nestor Gregorio ${ }^{2}$ \\ ${ }^{1}$ School of Integrative Systems, The University of Queensland, Brisbane, \\ Qld 4072, Australia \\ ${ }^{2}$ College of Forestry and Natural Resources, Visayas State University, Visca, \\ Baybay City, Leyte, the Philippines
}

\begin{abstract}
Visits to forestry agencies and seedling nurseries in Thailand and Vietnam revealed an impressive level of progress in regard to both industrial and small-scale forestry. In both countries, reforestation is accorded high priority, the government is a major player in nursery seedling production, and a high level of technology is used in producing seedlings. Universities also play an active role in forestry seedling production. The visit provided valuable lessons for seedling production systems in the Philippines, including information about the roles of government versus private nurseries and about seedling quality and nursery accreditation.
\end{abstract}

Keywords: Seedling certification, pulp and paper, framework plantings, forest restoration, acacia hybrid

\section{INTRODUCTION}

Visits were made to forestry agencies and seedling nurseries in Thailand and Vietnam between 10 February and 2 March 2008. The purpose of the trip was as set out in the ACIAR Philippines Seedling Enhancement Project document (Herbohn 2006), under Objective 1 - 'Examine the respective roles and effectiveness of the private and public sector in the tree nursery sector', as Task 1b 'Undertake a comparative analysis with other SE Asian countries'. ${ }^{\prime}$ This task is stated in more detail in Section 5.1 - 'Research Methodologies and Project Travel'.

The issues associated with nursery industry organisation and policy environment are not limited to the Philippines, but are common throughout south-east Asia. A comparison of the seedling production polices for smallholder and community plantations in the region is very likely to provide valuable information on how to improve policies in the Philippines, as well as useful guidance to agencies concerned with seedling production in neighbouring countries. Some countries in the region

${ }^{1}$ This project is formally known as Improving the Effectiveness and Efficiency of the Philippines Tree Nursery Sector (ASEM/2006/091). Another team examined forestry seedling production systems in Indonesia in December 2007. 
which appear to place a high priority on forestry expansion include Indonesia, Thailand and Vietnam.

This task proceeded concurrently with the production of a special double issue of Small-scale Forestry, which assembled 14 papers on forestry seedling production systems for smallholders in developing countries (Harrison et al. 2008a). Two of these papers were from Indonesia, and one each from Thailand and Vietnam. A review of the problems faced in seedling production for smallholder forestry in developing countries, and potential measures to overcome these problems, is provided by Harrison et al. (2008b) in the opening paper to this special issue, so further review material will not be provided here.

This paper sets out details of the sites visited in Thailand and Vietnam, the impressions gained, and then draws implications for forestry seedling production in the Philippines. The sites visited and people contacted are listed in Attachment A.

\section{FORESTRY SEEDLING POLICY AND PRACTICE IN THAILAND}

Four forestry agencies or sites were visited in Thailand, namely the Forest Restoration and Research Unit (FORRU) associated with Chiang Mai University in northern Thailand, the Royal Forest Department (the seedling nursery near Chiang Mai), the Regional Community Forestry Training Centre for Asia and the Pacific (RECOFTC), and the Forestry Faculty at Kasetsart University (KUFF).

\section{Visit Activities at Chiang Mai}

The Forest Restoration Research Unit headed by Dr Stephen Elliot at Chiang Mai University is concerned with restoration of degraded rainforest in several sites in Thailand. An early question for this research was 'Where is forest restoration appropriate?' The view was taken that forest restoration is appropriate wherever biodiversity is one of the goals of reforestation, including wildlife conservation, ecotourism and to supply a variety of forest products to local communities. This led to a focus on degraded sites within the Thai national parks and wildlife sanctuaries, which cover more than $15 \%$ of the country. As in many developing countries, some of these conservation areas contain large deforested sites, logged by former concessionaires or previously cleared for agriculture.

Since 1994, FORRU has been working to reforest areas previously used for agriculture in Doi Sutep-Pui National Park near Chiang Mai, with funding support from the WWF country program and corporate partner King Power Duty Free. This has been a cooperative effort with the Hmong people in the park. About 20 years ago, the loss of fresh water from a natural spring that supported a village caused the Hmong to relocate from their historical home to a new location at Ban Mae Sai Mai. FORRU adopts a policy that the view 'Tropical forests, once destroyed, are lost forever' is not true, and that it is possible to transform largely deforested landscapes into lush tropical forests, in a few years (Elliot et al. 2008). Forest restoration is viewed as a specialized form of reforestation.

FORRU operates a nursery producing seedlings of a wide range of native tree species for what is referred to as framework plantings in the park, and has developed seedling production and forest restoration techniques from research and 
experimentation over 15 years. The nursery has become a teaching facility and a popular visit site for forestry tours. The methods adopted by FORRU for forest restoration and for working with communities have evolved and been refined through a wide range of research projects at Chiang Mai University and communications with tropical forest biodiversity specialists in various countries.

The principles and framework species method adopted have been documented recently in a detailed handbook on principles and practices or restoring tropical forests, edited by Elliot et al. (2006). This is a long-term approach to reforestation, based on local knowledge and environmental circumstances. It begins with research into the composition of the native plant species of an area. Then, species in remnant forest patches that are fast-growing, hardy, and have high outplanting survival rates are chosen for seed collection, and seeds are cultivated in the FORRU nursery. The species planted are not designed to be the final species mix, so much as 'bait' to attract natural seed dispersers to operate in the newly planted areas.

In preparation for seed collection, a vegetation survey was conducted in the national park to identify framework species. Fortunately, walking tracks exist within the park (though these are neither signposted nor widely used by tourists), providing convenient access for the survey. Trees of more than 100 species were labelled, and detailed observations of flowering and fruit production were made at three week intervals over four years, enabling seed collection for the nursery to be scheduled.

Elliot et al. (2006) present details of 41 framework tree species identified as suitable for forest restoration in northern Thailand and neighbouring regions. Ficus species in particular have been found important, because they serve as a habitat and food source for birds and animals.

In general, removal of flora and fauna from a national park in Thailand, as in other countries, is illegal. However, this forest reproductive material (FRM) is used for replanting within the national park, and park authorities have come to accept the importance of the FORRU activities. No seedlings are sold by FORRU - they are given to the community, and some are given to the national park authority for their own use.

As well as the office and a research nursery at the national park headquarters, FORRU has a community nursery and field plots at Ban Mae Sa Mai. It also has an education unit in the Biology Department at Chiang Mai University. A visit was made to the FORRU nursery, which employs a manager and three staff. The nursery produces about 20,000 seedlings a year. Shading is provided from trees planted around the nursery, rather than any artificial covering system. A covered research and display area has been constructed, and a seed storage and germination area is netted to prevent entry by squirrels or other pests.

The wide variety of species grown in the nursery creates major challenges for seed collection, seed germination, potting mix, pot dimensions, pest control and other nursery operations. A substantial research program has been necessary to develop methods for dealing with this complexity of seedling production. This research has included some undergraduate student projects, although in general the student activities tend to be too short-term to provide a useful contribution. Germination trials have been carried out on more than 400 native forest tree species - both pioneer and 
climax species - including scarification, heat treatment, and soaking seeds in water and acid.

Experiments were conducted to determine the best container type and potting medium. Forest soil has proven a critical ingredient of potting mix, containing the mycorrhizal fungi necessary to promote seedling growth. In general, insecticides are not used in the nursery. Control of damping off in seedlings with fungicide (Captan or Thiram) is occasionally needed. Experience indicates that the optimal time for outplanting in the national park is at the beginning of the rainy season, which is typically one week during June. The critical window of opportunity for outplanting means that the timing of seedling production requires careful planning. Further detail on the FORRU activities is provided in Elliot and Kuaraska (2008).

\section{Seedling Production by the Royal Forest Department}

Forestry seedling production in Thailand is mainly undertaken by the government. The Royal Thai Forest Department (RFD) was established on September 1896, when forests were regarded as sufficiently abundant for people to cut or collect timber or forest products freely for their own uses or for commercial purposes, except teak (Tectona grandis Linn.).

The RFD has large-scale seedling nurseries in each of the forest districts in Thailand. A visit was made to the RFD nursery near Chiang Mai. This nursery produces about $1 \mathrm{M}$ seedlings a year, of which more than $50 \%$ are teak. The nursery employs 67 staff, and has a tissue culture laboratory for teak propagules. The tissue cultured propagules are mainly used as sources of cuttings for the mass seedling production. The tissue cultured propagules are potted and placed in the misting chamber and recovery shed before transfer to the transplant shed. The transplant shed has a double layer of shade cloth to reduce the solar radiation by $50 \%$. The potting mix is made up of compost, charred rice hulls and soil in a 2:1:5 mixture.

About 20 cuttings are obtained from each clonal plant over three years. These are established in a misting chamber or mist spray house holding 100,000 plants, over 2-3 weeks, and then grown in polybags or Rex trays in the nursery, with approximately daily hose watering. A disadvantage of the Rex trays (similar to hiko trays from Japan) is that it is not possible to grade the propagules.

About $60 \%$ of the seedlings are used for government plantation areas, and about $40 \%$ are distributed to private landholders. The landholders are required to place orders for seedlings in advance and must provide their identification card and evidence of property title, and demonstrate that they can transport the propagules. The seedling orders give the nursery an indication of how many propagules to produce. Individual farmers are typically provided with 200 propagules, but could be given up to 3000 . The production cost is about $3.5 \mathrm{bt} /$ propagule. The nursery cannot fully meet the demand, and there is no seedling carryover problem. Government subsidies are available to landholders to obtain seedlings.

A separate nursery area was also inspected, where concrete germination chambers containing a germination medium of sand and soil mix at the ratio of 4:1 are covered with plastic sheeting. These are used for germinating seeds of red gum (E. camaldulensis), narra (Pterocarpus indicus), jack fruit (Artocarpus heterophylla), and some other tree species. It was observed during the visit that female nursery staff were 
processing narra seeds, which is a highly regarded species in Thailand. Narra has a papery fruit, containing two seeds, and seed extraction is a labour-intensive process.

The RFD has a silvicultural research section, and many projects on teak and rattan (Calamus sp.) propogation have been carried out. The department's nurseries meet the needs of smallholders, providing high quality free forest reproductive materials, and there appears to be little scope for private nurseries to operate for non-industrial forestry. One of the objectives of the Thailand National Forest Policy is that incentive systems shall be established to promote reforestation by the private sector, but no evidence of this activity was identified.

\section{Activities of the Forest Industry Organization}

The other major seedling producer in Thailand is the Forest Industry Organization (FIO). This is a government enterprise under the administration of the Ministry of Natural Resources and Environment, which was founded in 1947, and authorized through Royal Decree in 1955. It is charged to: be responsible for reforestation and silviculture; generate income from the forest industry and related activities; conduct forestry research; increase public awareness of the importance of forest conservation; and provide the public with tourism facilities (FIO 2008).

According to Rajesh (2001), the Thai government declared a nation-wide ban on logging concessions in 1989, which deprived the agency of its logging revenues. In July 2001, the FIO received 'sustainable management' certification of two teak plantations. At that time the FIO had a total of 160,000 ha of tree plantations, mainly of teak, rubber and eucalypts, and owned three sawmills.

The FIO currently manages 185,600 ha of teak (51\% of area), and areas of eucalypt (17\%), rubber trees (5\%) and other species in the forest reserve areas in Thailand, and operates sawmills and wood processing plants (FIO 2008). It operates large-scale seedling nurseries, and uses tissue culture for producing teak FRM. Unlike the RFD, the FIO nurseries do not distribute seedlings to private growers. However, the organization operates a modified taungya (food cropping within young plantations) with rural and tribal inhabitants who have traditionally subsisted on shifting cultivation.

In general, the nurseries of both the RFD and the FIO produce a narrow range of seedlings, dominated by teak and designed to maximize timber production, although there has been some widening of species produced and some focus on permanent plantings in recent years, prompted by the growing environmental movement in Thailand. Some large private nurseries also operate in Thailand, but in general the availability of free high quality seedlings from RFD nurseries crowds out the private sector from competing in seedling production.

\section{The Activities of the Regional Community Forestry Training Centre for Asia and the Pacific (RECOFTC)}

RECOFTC (http://www.recoftc.org/site/) is an international non-profit organization, established in 1987, which carries out activities in the Asia-Pacific region comprising 47 United Nations member countries. It has headquarters with visitor accommodation and lecture rooms at Kasetsart University in Bangkok, although it is independent of the university. RECOFTC currently has country offices and programs in Indonesia, 
Cambodia and Thailand, the Thai program being quite a large with a number of field sites throughout the country. The main units within the organizational structure are Regional Analysis and Representation (RAR), Capacity Building Services (CABS), Country Program Support (COPS), and Program Planning and Delivery (PROP).

RECOFTC works closely with other agencies to promote multi-stakeholder dialogues and promote equitable and sustainable management of forest and other natural resources in the Asia-Pacific region. Core donors include the Swiss Agency for Development and Cooperation, the Swedish International Development Cooperation Agency, and the Ministry of Foreign Affairs, Norway.

RECOFTC follows a strategy of promoting active participation of local communities in developing and managing forest resources. Currently RECOFTC has about 65 personnel and an extensive network of associates and consultants. Its staff members are of diverse nationalities, including from Australia, Cambodia, Germany, India, Indonesia, Ireland, Nepal, New Zealand, South Africa, Thailand, the United Kingdom, the United States and Zimbabwe. RECOFTC offers customized training and study tours. The vision of the Centre is to see local communities in the Asia-Pacific region actively involved in the equitable and ecologically sustainable management of forest landscapes. The mission is to enhance capacities at all levels to assist people of the Asia-Pacific region to develop community forestry and manage forest resources for optimum social, economic and environmental benefits.

RECOFTC's major areas of interest and expertise include:

1. Ecological systems, e.g. mountain, arid, and semi-arid areas, and coastal zones.

2. Landscapes, e.g. all types of forests (natural and planted, watershed areas, protected areas, villages, agricultural land).

3. Tenurial systems, e.g. legal and customary or de facto management and ownership arrangements.

4. Sustainable livelihoods and poverty reduction through forests and non-timber forest products.

Four major themes are addressed, namely Rural Livelihoods and Poverty Reduction, Forest Governance, Productive and Sustainable Forest Management, and Communities and Protected Areas. Cross-cutting issues are identified as non-timber forest products and services (NTFPS), benefit sharing, payment for environmental services (PES) and reduced emissions from deforestation (RED). The Centre deals with a wide variety of stakeholders, and operates through strategic partnerships with numerous institutions, programs, projects and networks. Some of the activity areas include: Capacity Building Products and Services; Training Programs and Study Tours; Customizing Services to Suit Clients Needs; Training and Capacity Building Needs Assessment; and Facilitation of Learning Processes.

The Centre has a well-stocked library on community forestry, and produces a wide range of publications, including books, papers, newsletters, training manuals and materials, seminar proceedings, and workshop reports.

While RECOFTC's activities are clearly in the area of forestry promotion, its training focus, and indeed 'training the trainers', is somewhat removed from direct 
activity in reforestation. It does not appear to have significant policies with respect to seedling production.

Short meetings were held with Dr Peter Stephen and Dr John Guernier, who explained some of the activities of RECOFTC. There has been increased emphasis on in-country training, rather than using the facilities in Bangkok. The impression gained from discussions was that industrial producers are increasingly dominating forestry in Thailand.

\section{Visit to the Faculty of Forestry, Kasetsart University}

Brief meetings were held with Andrew Warner and Monton Jamroenprucksa of the Forestry Faculty at Kasetsart University (KUFF). Dr Warner has spent over 30 years of professional forestry work in plantation and native forest management, with the last 12 years as a senior team member in Private Forests Tasmania, the government agency that provides advice on all aspects of sustainable use of trees on private land $(40 \%$ of Tasmania's forests are privately owned). After early retirement, he followed a longheld ambition to participate in south-east Asian projects that involve private forestry, capacity building and mensuration.

Professor Monton Jamroenprucksa is head of the Department of Silviculture, in the Faculty of Forestry at Kasetsart University. He noted that the Forest Industry Organization is concerned with fast growing species, for which there are many plantations in the forest reserve (an area which previously had little forestry). This contrasts with the RFD, which dominates tree planting on private land. An area of about $2 \mathrm{M}$ rai is planted on the holdings of about 100,000 farmers, who receive a subsidy of about 3000 bt/rai over five years ${ }^{2}$. The farmers are either given free seedlings or given the subsidy. Timber is often difficult for farmers to market, and unfortunately some farmers cut down the trees prematurely to plant crops including oil palm which is more profitable. Teak cannot be harvested until an age of about 30 years, although some revenue can be generated from thinnings. Much genetic improvement has been carried out for teak, and now hybrids are produced with controlled pollination.

In discussions it was noted that the private forestry sector has tissue culture laboratories and nurseries, and also large plantations. They do sell seedlings to farmers. Eucalypts are widely grown in Thailand, for paper and pulp production. The government provides seedlings of a range of tree species, including native species and dipterocarps. The Kasetsart Forestry Faculty would like to influence the government to support small nurseries.

Kasetsart University hosted an international conference on Tropical Forest Change in a Changing World (FORTROP 2 for short), over 17-20 November 2008, with about 400 delegates. Authors provided full papers prior to the conference, but proceedings are yet to be produced.

\footnotetext{
${ }^{2} 1$ ha $=6.25$ rai, $\$ 1 \mathrm{~A}=25$ Thai baht approximately.
} 


\section{Overview of Seedling Production Policy in Thailand}

Thailand has a ban on logging native forests, and a policy of promoting forestry development. The government, through the RFD, provides free seedlings to private producers. However, the quantity produced appears to fall well short of demand. No doubt, some private seedling nurseries exist, some perhaps relatively large, and some farmers grow their own seedlings, but seedling production is dominated by the RFD and the FIO, both of which use high technology nursery systems.

In general, the seedling nurseries of both the RFD and the FIO produce large quantities of a narrow range of seedlings, dominated by teak and eucalypts and designed to maximize timber production, although there has been some widening of species produced and some focus on permanent plantings in recent years, prompted by the growing environmental movement in Thailand. While some private nurseries also operate in Thailand, in general the availability of free high quality seedlings from RFD nurseries crowds out the private sector from competing in seedling production. Some relatively small projects support reforestation in ethnic communities, using a wide variety of native species, of which FORRU is a notable example.

Forestry in Thailand is supported by a strong research contribution from government and universities (notably Kasetsart). The RECOFTC, which has its headquarters in Bangkok, plays an indirect but major role in promoting reforestation and community forestry, through capacity building in various south-east Asian countries.

\section{FORESTRY SEEDLING POLICY AND PRACTICE IN VIETNAM}

Forestry in Vietnam has been undergoing rapid change in recent years (Hieu, 2004; Nguyen and Noriko. 2008). Four forestry agencies or sites were visited to explore changes with respect to nursery seedling production, namely the Forest Science Institute of Vietnam (FSIV), the Vietnam Forestry University (VFU), the Phu Tho Research Institute of Pulp and Paper Raw Material Tree Species (internationally known by the earlier name of Forest Research Centre, FRC) at Phu Ninh, Phu Tho Province, and the Department of Forestry within the Ministry of Agriculture and Rural Development in Hanoi. As well, meetings were held with Geoff Morris, ACIAR Country Manager, Australian Embassy, and Bui Hoa Binh and Ho Kien Trung of the Environmental Protection Agency in Hanoi.

Four forestry agencies or sites were visited in Vietnam, namely the Forest Science Institute of Vietnam (FSIV), the Forestry University of Vietnam (VFU), the Forest Research Centre at Phu Ninh, Phu Tho Province, and the Department of Forestry within the Ministry of Agriculture and Rural Development in Hanoi. As well, meetings were held with Geoff Morris, ACIAR Country Manager, Australian Embassy, and Bui Binh Hoa and Ho Kien Trung of the Environmental Protection Agency in Hanoi.

Vietnam is implementing major programs for forest industry expansion, including the Five Million Hectare (5MH) Project, to establish $5 \mathrm{M}$ ha of plantations. A highly detailed seedling production policy has been developed, reported in the MARD (2006) document 'Decision on Approval of the Forest Reproductive Materials Development Strategy for 2006-2020’. 


\section{History and Functions of the Forest Science Institute of Vietnam (FSIV)}

A meeting was held with Dr Pham Duc Chien, Vice-Head of the FSIV Science and Planning Division, and other staff members. As noted on the FSIV website (http://www.fsiv.org.vn/), the institute was established by merging three institutes, namely the Forest Research Institute, the Forest Industry Institute and the Forest Economics Institute. The FSIV is the main research organization for forestry in Vietnam and is under the direct guidance of the Ministry of Agriculture and Rural Development (MARD). The institute employs about 500 staff including 200 where the institute is based in Hanoi; there is also a South Vietnam Forest Science Sub-Institute as well as regional centres.

The functions and tasks of the FSIV are listed on the web site as:

1. Organizing and implementing scientific and technological research on silviculture, forest industry, forest economics, forestry organization and management, serving the requirements in development of the branch, and developing a tropical forest science of Vietnam.

2. Elaborating and implementing forest socio-economic, scientific and technical programs; developing an economic management mechanism, technical procedures and economic and technical standards.

3. Training researchers in various fields of forest science; fostering and upgrading scientific knowledge for scientists, technicians and managerial personnel in the forestry branch.

4. Carrying out international cooperation programs.

5. Providing a consultancy service for forestry investment.

FSIV has a number of specialized research divisions and centres performing scientific and technical research functions, including:

Forest Tree Improvement Research Centre

Non-timber Forest Products Research Centre

Forest Ecology and Environment Research Centre

Silvicultural Techniques Research Division

Plant Resource Research Division

Forest Protection Research Division

Forest Engineering Research Division

Forest Product Research Division

Forest Product Preservation Research Division

Forest Economics Research Division

FSIV produces seed of forestry species, which are distributed free in a few projects but are mostly sold to other nurseries and tree growers.

Protection forest has been given assistance under the $5 \mathrm{MH}$ project. The idea is to have $60 \%$ fast growing species and $40 \%$ slow growing species in protection forest 
plantings, with the latter to be permanent plantings. However, the fast growing species suppress the slow growers (with the result that most of the trees planted are harvested), so the proportion of fast growing species in these plantings should be reduced. Large companies are now investing in forestry in Vietnam.

In Vietnam, seedlings are produced by three categories in nurseries, namely state enterprises, private enterprises and household nurseries. MARD has a seed certification scheme, which applies to companies and organizations. The scheme provides assurance that seedlings are of high genetic quality. Extension activities are also carried out to encourage the use of high quality seedlings. (There is a National Agriculture Extension Centre within MARD.) Notably, certification allows nurseries to obtain higher prices for seedlings, and to sell seedlings to state enterprises. The state tree breeding centre (the Research Centre for Forest Tree Improvement, Vietnam) has a good reputation because it has been operating for a number of years and the seedlings have a reputation for high quality.

\section{Meeting with Geoff Morris, ACIAR Country Manager, Australian Embassy}

A meeting was held with Geoff Morris, who had taken up the role of ACIAR country manager for Vietnam eight months earlier. Mr Morris has a strong interest in forestry, having previously been a volunteer with FSIV and working with Dr Chien. $\mathrm{He}$ and Hieu Phan Sy (undertaking PhD studies at UQ with a John Allright Fellowship) authored a paper on conservation of rare forestry species in the special issue of Small-scale Forestry on seedling production systems. The paper is a condensed version of a research report funded by Flora and Fauna International.

$\mathrm{Mr}$ Morris commented that the FRC, which received funding support from Sweden, provides a good model of a tissue culture laboratory. This laboratory produces planting material for plantations providing timber to the pulp mill near the FRC in Phu Ninh (which was established by Sweden but is probably now $100 \%$ Vietnamese-owned). Mr Morris further commented that there could be many tissue culture laboratories operating in five years time. A tissue culture laboratory has been established to support a forestry nursery in the Hoang Lien National Park. While many forestry stakeholders would like to have a tissue culture laboratory, unfortunately some of these laboratories do not survive in production in the long term.

The Five Million Hectare $(5 \mathrm{MH})$ program, which is generating a strong demand for seedlings, was originally scheduled to run until 2010, but now is to run until 2020. Vietnam has $18 \mathrm{M}$ ha of forestland, including $12 \mathrm{M}$ ha of forest. Some of the planted area statistics are unreliable, because areas which had to be replanted are counted twice. Still, there have been large plantings, especially of production forest. No-one appears to be growing the high-value long-rotation tree species. There is a big demand for eucalypts for pulp, and large areas of eucalypts are being planted for this purpose. There are hundreds of small household forestry seedling nurseries in northern Vietnam. Small nurseries obtain seed from local nurseries and seed companies and can also access FRC planting material. Nurseries trust the local suppliers with respect to seed quality. 


\section{Visit to the Vietnam Forest University (VFU)}

A meeting was held at the campus with Dr Le Sy Viet (head of the Silvicultural Department), the dean and the head of the Department of Biology. Dr Viet has travelled widely, including to Australia. Vietnam Forestry University (VFU, http://www.ntviet.com/comp.htm) was founded 1964, through the separation of the Faculty of Silviculture and Forestry Mechanization from Hanoi Agriculture and Forestry University. The university moved to the present site in Ha Tay province (now a district of of Hanoi) in 1984. The university is administered by MARD, but is managed by the Ministry of Education and Training in terms of educational and professional quality. The university provides undergraduate and postgraduate programs in forestry and rural development, and research and technological transfer in forestry and rural development.

VFU is the only forestry university in Vietnam, and has about 13,000 students, including several thousand in-service students. By 2009, about 20000 engineers, 600 masters and $40 \mathrm{PhD}$ students were graduated and trained by VFU. There were about 350 teaching staff; three masters degree and $10 \mathrm{PhD}$ students were enrolled in 2008. The enrolment is increasing each year. Courses in forestry are not popular in Ho Chi Minh City. The main VFU campus consists of 27 ha, and the university has been allocated more than 400 ha of forestland for practical forestry, research and training. The university has a tropical forest plant collection arboretum for indigenous species gene bank preservation from every part of Vietnam and demonstration models for research and trials on forest farms and social forestry. Training majors include Silviculture, Resources and Environment Management, Industry for Rural Development, Business Management, Forest Products Processing, Social Forestry, Urban Forestry, Forestry Mechanization and Forestry Economics. An Ecosystem and Land Management program was also recently introduced. VFU has one project on the clean development mechanism (CDM) ${ }^{3}$, funded by Honda.

VFU is located in an area that will become one of a series of satellite cities surrounding Hanoi capital in the near future. It is situated on the semi-mountainous land that is the gate to the Northwest region linking with Hanoi capital as well as the junction of the road No 6A (Hanoi - Hoa Binh) and road No 21A (Xuan Mai - Son Tay), $35 \mathrm{~km}$ SW of Hanoi.

A visit was made to the tissue culture laboratory on campus, which, though relatively small, adopts high technology and is a valuable training facility. Acacia and eucalypt forest reproductive materials are produced; indigenous species (including melia) are grown from seed. The demand for forest reproductive materials (FRM) is high due to the $5 \mathrm{MH}$ program, and allocation of land by the state to farmers. Some seed for acacias and eucalypts is imported from Australia. Selected mother trees are now used for material for tissue culture. There is a high demand for this FRM because of the high quality.

${ }^{3}$ According to Wikipedia, the Clean Development Mechanism (CDM) is an arrangement under the Kyoto Protocol allowing industrialised countries with a greenhouse gas reduction commitment (called Annex B countries) to invest in projects that reduce emissions in developing countries as an alternative to more expensive emission reductions in their own countries. 
A seedling certification program is operated by the Department of Forestry in MARD. A committee in Hanoi assesses quality, and has been operating for two years. There is a Central Seed Company. The certification involves both genetic and physical criteria. The provincial offices of MARD organize many training courses. If a group is supported by government, they are required to use high quality seedlings, but those growing trees on private land can obtain seedlings from any source. There are no legal impediments to setting up seedling nurseries, and there is a very large number of household nurseries in the area; most of these are very small, and their seedling quality is low. Seed is collected from the forest. In some areas the planting of Australian melaluca is mandated, for soil erosion control and bee culture.

VFU obtains seed for Pinus merkusii from a seed plantation. The main seed source for VFU is their own company and other private companies. No private companies have a large forest area, in contrast to state companies. They have changed from state companies to Joint Stock companies. There are both state and private joint stock companies, the forestry company of VFU being of the former type.

Private farmers have very small plantations, often of 1-2 ha, and they mostly only plant under contract with a seed company. VFU would like to produce seedlings for many indigenous species, but only a few are in demand. In Vietnam, there are more than $9 \mathrm{M}$ ha of natural forest, two thirds of which is special use or protection forest and one third of which is production forest; there are also about $3 \mathrm{M}$ ha of plantation forest. Farmers can obtain assistance for growing protection forest, in which limited harvesting is allowed.

The VFU owns forestry nurseries producing $10 \mathrm{M}$ seedlings a year, in three nurseries, operated by a company formed by the university, called the Consultant Investment Company of Forestry Development. It is a self-managed company, earning revenue from contracts, and contributing to university funds. The company, which employs about 150 staff, sells seedlings to farmers and to production forestry companies. The nursery network is a profitable operation for VFU. The nurseries are well separated because of land availability and to be close to seedling buyers. Industrial buyers are the main customers.

The company grows $A$. mangium, with a harvest age of 7-8 years and a yield of about $150 \mathrm{~m}^{3} / \mathrm{ha}$. The company grows acacia hybrids (Acacia auriculaeformis $\mathrm{x}$ Acacia mangium), eucalypts (including E. urophylla) and Manglietia glauca. The acacia hybrid was bred at the FSIV, and won a science prize. It is prone to wind damage. The price of eucalypt timber is about $1 \mathrm{M} \mathrm{VND} / \mathrm{m}^{3}$ while that of mangium for pulp and fibre board is about $2 \mathrm{VND} / \mathrm{m}^{3,4}$. Mangium timber attracts a higher price, and the hybrid has a MAI of $30 \mathrm{~m}^{3} / \mathrm{ha}$. Cuttings are used in some cases for acacias and eucalypts. Seedling production costs about $1000 \mathrm{VND} /$ seedling, and there is a price mark-up of about $70 \%$ for acacia and eucalypt seedlings when they are sold.

Visits were made to a large nearby nursery producing $3 \mathrm{M}$ seedlings a year, and a smaller nursery at the company headquarters. At the first of these nurseries, the company manager explained some of the activities and then the nursery was inspected.

\footnotetext{
${ }^{4} \$ 1 \mathrm{~A}=12,000$ Vietnamese dong (VND), approximately.
} 
Steady rain made inspection difficult. The nursery uses seed as FRM, except for $E$. urophylla.

VFU practices direct seeding of Acacia mangium into 3 inch x 1 inch diameter nylon bags in seedbeds. It was not clear whether the seedlings could then be planted out, or whether root pruning and re-potting would be needed. Female workers in the nursery are highly skilled in potting up seedlings. Acacia cuttings were seen to be grown in soil with a high clay content. There was a substantial number of dead acacia seedlings, probably due to damping off. Notably, seedlings were placed on the ground, with no spacers and the polybags covered with soil. The seedlings are held in the nursery for about three months. Eucalypt seedlings from tissue culture jars were placed in nylon bags in beds under a tent about $80 \mathrm{~cm}$ in height. The nursery had an excellent water supply from a shallow well.

In the nursery at the company headquarters, there were beds of seedlings, including the high-value native species of dalbergia and magletia. Dalbergia was said to be used in vodka and to improve hearing (though the particular species and plant part was not clear), and priced by the kilogram. A web search indicated that Dalbergia cochinchinensis is used in the production of vodka and other spirits, while Dalbergia sissoo is classed as a medicinal and aromatic plant.

\section{Visit to the Forest Research Centre at Phu Ninh, Phu Tho}

The visit to the FRC, an institute of the Vietnam State Paper Corporation, which was previously a focal point for the ACIAR project led by Dr David Lamb and Dr Huynh Duc Nhan, was a highlight of the trip to Vietnam. A meeting was held with Dr Ha Van Huy (the director) and a colleague, and then with about 15 institute staff, followed by a tour of the tissue culture laboratory. After lunch a comprehensive inspection of the seedling nursery was facilitated.

The FRC was established in 1973, supported by funds from the Swedish government for the Bai Bang paper mill $2 \mathrm{~km}$ from the centre. (The FRC has another centre in a distant location with a seed orchard for mangium.) The centre produces FRM of several species and cultivars suitable for raw material. Much of the timber is grown by a government forest enterprise, on forestland. Five provinces each had a forestry project, and the FRC linked them together. The FRC previously provided training in nursery techniques, but now only provides technical support for nurseries.

The centre sells seedlings to farmers, but does not distribute free seedlings. Funding has been tightened by governments for all research institutes. The government now only meets $50 \%$ of the FRC costs. The main customers are companies, farmers having little land to grow trees. Some nurseries purchase FRM from the tissue culture laboratory (large numbers of tiny plants in trays of agar medium).

The centre sells seeds, seedlings and clonal FRM. About $6 \mathrm{M}$ seedlings were sold last year, plus $3 \mathrm{M}$ propagules from the tissue culture lab, which included hybrid acacia. Seeds for indigenous species are purchased from the owner of a seed orchard.

The FRC must follow the certification procedure, as set out in the manual developed by MARD with the assistance of Danida (the development cooperation agency with the Danish Ministry of Foreign Affairs). Smallholder nurseries receive 
about two-thirds of the seedling price obtained by the FRC, but seedling production is still profitable compared with growing other crops and other trees.

The Bai Bang pulp and paper mill was established by the Swedish International Development Cooperation Agency (SIDA) over 1975-1983, though not reaching design capacity until 1996, and was a highly controversial project in both countries. It now produces 152,000 tonnes of paper and pulp a year, and plans to substantially expand production. Forestry enterprises grow the trees, financed by money borrowed from the government. Eucalypt and acacia timber when grown near rivers (Thao and Red river) is transported by river; mangelita and other native species are transported by road. Farmers can grow trees on private land, or in cooperation with the timber enterprises. In the first case, the farm gate price is only $50 \%$ of the mill door price. There is a below-market interest rate of $8.4 \%$ for farmers, with repayment over seven years. The rotation has been reduced from 10 years to seven (and even six and five). The paper companies have given the FRC the responsibility to reduce rotation length.

The FRC provides training to farmers, including at the commune level. Financial assistance for farmers is available from two banks, namely the Vietnam Development Bank (VDB) and Vietnam Bank of Agriculture and Rural Development. Funds are also provided by a government bank for poor people. The application for funds must first have approval from the commune, either for an individual farmer or as a group. The land can belong to the government or the commune or group, and if the latter, must have appropriate land title. The nurseries purchase only seeds or germinants from the FRC. A permit is required to operate the nursery, a government permit to sell seedlings, and a certificate of the seedlings is issued by the FRC.

Acacia FRM grown from seed is priced at 300 VND per seedling, and eucalypt from seed 650 to 700 VND. Hybrid acacia (Acacia auriculaeformis x Acacia mangium) from cuttings is priced at 400-450 VND. The small farmer nurseries can sell at a lower price and have low volume, which is not suitable for large orders. Nurseries can buy seedlings from the FRC to sell on. There is a demand for $7 \mathrm{M}$ germinants from the tissue culture lab this year, but the output capacity is only $3 \mathrm{M}$. The price of seed sold to farmers and timber enterprises must be stated on the sale permit, and is controlled by government. The paper corporation approves the price of the seed, which varies between locations depending on the cost of seed collection. The paper company agrees on a price of $1 \mathrm{M} \mathrm{VND} / \mathrm{kg}$. The paper company puts money into seed production.

\section{Visit to the Department of Forestry within MARD}

A short meeting was held with Dr Pham Duc Tuan of the Department of Forestry within the Ministry of Agriculture and Rural Development. Dr Tuan provided a copy of the very comprehensive 'Essential Documents on Management and Technologies for Forest Reproductive Materials in Vietnam' prepared by the Department and DANIDA. 


\section{IMPLICATIONS FOR SEEDLING POLICY AND PRACTICE IN THE PHILIPPINES}

Production of seedlings for forestry plantations in both Thailand and Vietnam - for both industrial and smallholder forestry - is conducted at a large scale and is technologically advanced. In both countries, the government plays a major role, although the private sector is increasingly involved in Vietnam.

There is a high demand for forestry seedlings in Vietnam, due to the high tree planting targets, especially under the $5 \mathrm{MH}$ program. A reasonably sophisticated system of both seed and seedling production has been established in Vietnam, with a strong incentive for certification being access to government seedling supply contracts. The large scale of tree planting in Vietnam under the $5 \mathrm{MH}$ program dwarfs the Philippine Trees for Life project, with a target of $25 \mathrm{M}$ seedlings. The national networking of forestry including seedling production in Vietnam is impressive, and raises the question of whether greater networking in forestry seedling production should be pursued in the Philippines.

Progress in seedling nursery systems in Thailand and Vietnam provides important lessons for the Philippines. There is a critical need for high quality planting stock in tree planting programs in the Philippines. One of the major reasons for the failure of government and private reforestation activities is the use of low quality planting stock. Most private and public nursery seedling production still uses germplasm from unselected sources. The high quality germplasm pathway is not well established in the Philippines. There are limited sources of genetically superior planting materials and technology on the production of high quality planting stock is not well advanced; for example, the use of tissue cultured germplasm is still not well known by nursery operators.

\section{National Networking}

There is a big scope for international networking to improve the germplasm pathway in the Philippines. Vietnam has gone a long way in terms of developing technologies and implementing policies to ensure the production and use of genetically improved materials in the country's tree planting programs. Accordingly, Vietnam could be a useful network to Philippines especially on the aspect of promoting an effective and efficient pathway of germplasm with high genetic quality.

\section{Certification (plus Branding and Higher Seedling Prices), Research and Extension}

The accreditation of forest nurseries which is being done in Vietnam is not currently observed in the Philippines. There is no national protocol that regulates the quality of seedlings from private and government nurseries. A research project funded by ACIAR is currently being implemented in the Philippines with the objective of developing policies to improve the supply of high quality seedlings and promote the financial viability of the nursery sector. In one of the workshops held by the project with various stakeholder groups, nursery accreditation was identified as an intervention to address the weak market of seedlings and low quality of seedling production. Accredited nurseries will produce high quality seedlings which command a higher price. 


\section{Species Choice (Indigenous, Exotic)}

Forestry seedling production in the Philippines is limited to a few common species, mostly exotics. The limited species base of seedlings is due to the limited availability of germplasm. This is particularly true for premium native species, especially dipterocarps, because of long interval between seed years and the scarcity of mother trees. The tissue culture technology in Thailand and Vietnam and the macro-somatic propagation of teak in Thailand could be popularized in the Philippines to facilitate the production of seedlings of a wide species base. This will increase the options of tree farmers in selecting the species to plant and help solve the problem of planting species outside of their environmental requirements.

\section{Producing Seedlings for Small-scale Versus Government Nurseries}

The presence of small-scale private nurseries is evident in Thailand and Vietnam, which is similar in the Philippines. The crowding out of small-scale private nurseries in Thailand is a situation that is also evident in the Philippines. However, in Vietnam and Thailand, the existence of small-scale private nursery is not very critical in meeting the demand of planting materials for state and private plantations. The government nurseries have sufficient technologies and resources to produce seedlings needed by the country. The case in the Philippines is different. The government nurseries in the Philippines do not have sufficient resources (e.g. financial, equipment and labour) to carry out large scale production of high quality seedlings to meet the country's seedling requirement. Accordingly, the existence of smallholder private nurseries is crucial.

\section{Appropriate Technology}

In terms of the production of planting stock for forest trees, Thailand and Vietnam are apparently considerably more advanced than Philippines. A tissue culture laboratory is a common facility in government and some large-scale private nurseries. The impressive seedling production facilities and technologies in Thailand and Vietnam could be used in the Philippines. Surveys have revealed that most of the small-scale private nursery operators in the Philippines lack information on appropriate seedling production technologies.

\section{Seedling Pricing}

The sustainability of the small-scale private seedling production in the Philippines is hampered by low financial viability of the nursery enterprise. The common production of low quality planting stock results in low seedling sales quantity and low prices. The use of appropriate seedling production technologies such as those practiced in Vietnam and Thailand will improve the quality of seedlings from the nurseries in the Philippines and consequently increase the financial viability of nursery seedling businesses. The ACIAR Seedling Enhancement Project in the Philippines is developing strategies to improve the financial viability of forest nurseries. One of the interventions is the introduction of best management practices to smallholders that were taken from research results, nursery manuals and observations of the seedling nursery industry in Thailand, Indonesia and Vietnam. 


\section{Certification and BMP}

Nursery accreditation and seedling certification is viewed as a sound intervention for improving the operational effectiveness of the nursery industry in the Philippines. The ACIAR Seedling Enhancement Project has been carrying out activities towards institutionalizing the nursery accreditation policy to be piloted on Leyte and Mindanao islands. Meetings and workshops with various stakeholders have been conducted and training classes with nursery operators. A manual on best management practice (BMP) is being developed to be used as the basis for the technologies to be adopted by the nursery operators with accredited nurseries. The technologies presented in the manual include those that were observed in Thailand, Indonesia and Vietnam.

\section{CONCLUDING COMMENTS}

Both Thailand and Vietnam suffered major forest destruction in the second half of the 20th century, and both countries have taken determined and well targeted steps to increase tree cover and promote forest industries. This has included large-scale seedling production and an emphasis on seedling genetic quality. The Philippines has much to learn from the actions and experiences in both of these countries.

While seedling production for both industrial and smallholder forestry is dominated by government in both Thailand and Vietnam, government provision of free seedlings retards the private nursery section in Thailand whereas there is much more private seedling production in Vietnam where the government charges for seedlings. The Vietnam system of seed and seedling certification for both government and private nurseries is perhaps one to which the Philippines could aspire. The application of the framework method for forest restoration in Thailand, which involves production of seedlings of a wide range of indigenous species, could perhaps be adopted for watershed protection in the Philippines.

\section{REFERENCES}

DEPARTMENT OF FORESTRY and DANIDA 2007. Essential Documents on Management and Technologies for Forest Reproductive Materials in Vietnam. Vietnam Tree Seed Project, Ministry of Agriculture and Rural Development, Hanoi.

ELLIOT, S., BLAKESLEY, D., MAXEWELL, J.D., DOUST, S. and S. SUWANNARATANA. 2006. How to Plant a Forest: The Principles and Practice of Restoring Tropical Forests. The Forest Restoration Research Unit, Chiang Mai University.

ELLIOT, S. and C. KUARASKA. 2008. Producing framework tree species for restoring forest ecosystems in Northern Thailand. Small-scale Forestry. 7(3-4): 403-415.

FIO (Forest Industry Organization). 2008. Information Brochure. Ministry of Natural Resources and Environment, Bangkok.

HARRISON, S., GREGORIO, N. and J. HERBOHN. 2008a. Small-scale Forestry, Special Issue on Seedling Production Systems. 7(3-4). 
HARRISON, S., GREGORIO, N. and J. HERBOHN. 2008b. A critical overview of seedling production policies and practices in relation to smallholder forestry in developing countries. Small-scale Forestry, Special Issue on Seedling Production Systems. 7(3-4): 207-233.

MARD (Ministry of Agriculture and Rural Development). 2006. Decision on Approval of the Forest Reproductive Materials Development Strategy for 2006-2020. Socialist Republic of Vietnam, Hanoi.

NGUYEN, V.Q. and S. NORIKO. 2008. Forest allocation policy and level of forest dependency of economic household groups: a case study in Northern Central Vietnam. Small-scale Forestry. 7(1): 49-66.

PHAN, SY HIEU. 2004. The changing administration and role of forestry in the economy of Vietnam. Small-scale Forest Economics, Management and Policy. 3(1): 85-98.

RAJESH, N. 2001. Forest Stewardship Council (FSC) certifies Thailand's chief logging agency. World Rainforest Movement. Last accessed 17 April 2008. www.wrm.org.uy/bulletin/48/Thailand.html. 


\section{Attachment A: Sites Visited and People Contacted}

\begin{tabular}{|c|c|c|}
\hline Country and date & Event or agency & Contact persons \\
\hline $\begin{array}{l}\text { The Philippines, } \\
13 \text { February }\end{array}$ & $\begin{array}{lcr}\text { Seedling } & \text { Sector } & \text { Policy } \\
\text { Modelling } & \text { and } & \text { Analysis } \\
\text { Workshop } & & \end{array}$ & $\begin{array}{l}\text { ACIAR project members from } \\
\text { Visayas State University and } \\
\text { The University of Queensland, } \\
\text { and DENR staff from Leyte } \\
\text { and Mindanao }\end{array}$ \\
\hline $\begin{array}{l}\text { The Philippines, } \\
13 \text { February }\end{array}$ & $\begin{array}{l}\text { Enhancing Tree Seedling } \\
\text { Supply via Economic and } \\
\text { Policy Changes in the } \\
\text { Philippines Nursery Sector: } \\
\text { Planning And Implementation } \\
\text { Workshop }\end{array}$ & $\begin{array}{l}\text { ACIAR project members from } \\
\text { Visayas State University and } \\
\text { The University of Queensland, } \\
\text { and DENR staff from Leyte } \\
\text { and Mindanao }\end{array}$ \\
\hline $\begin{array}{l}\text { Chiang Mai, } \\
\text { Thailand, } \\
18 \text { February }\end{array}$ & $\begin{array}{l}\text { Forest Restoration Research } \\
\text { Unit, Nursery Site }\end{array}$ & $\begin{array}{l}\text { Dr Peter Elliot and } \mathrm{Mr} \\
\text { Cherdsak Kuaraksa (Nursery } \\
\text { Manager) }\end{array}$ \\
\hline $\begin{array}{l}\text { Chiang Mai, } \\
\text { Thailand, } \\
19 \text { February }\end{array}$ & $\begin{array}{l}\text { Thai Royal Forest Department } \\
\text { Nursery }\end{array}$ & $\begin{array}{l}\text { Mr Cherdsak Kuaraksa and } \\
\text { nursery staff }\end{array}$ \\
\hline $\begin{array}{l}\text { Bangkok, } \\
20 \text { February }\end{array}$ & $\begin{array}{l}\text { Regional Community Forestry } \\
\text { Training Centre for Asia and } \\
\text { the Pacific, and Kasetsart } \\
\text { University }\end{array}$ & $\begin{array}{lll}\text { Peter } & \text { Stephen, } & \text { Andrew } \\
\text { Warner, Yam Malla, Monton } \\
\text { Jamroenprucksa }\end{array}$ \\
\hline \multirow[t]{2}{*}{$\begin{array}{l}\text { Hanoi, } \\
25 \text { February }\end{array}$} & $\begin{array}{l}\text { Forest Science Institute of } \\
\text { Vietnam (FSIV) }\end{array}$ & $\begin{array}{l}\text { Dr Pham Duc Chien, Tran } \\
\text { Lam Dong, Nguyen Quang } \\
\text { Khai, and others }\end{array}$ \\
\hline & Australian Embassy & $\begin{array}{l}\text { Geoff Morris, Kieu Xuan } \\
\text { Hung }\end{array}$ \\
\hline $\begin{array}{l}\text { Hanoi, } \\
26 \text { February }\end{array}$ & $\begin{array}{l}\text { Vietnam Forest University } \\
\text { (VFU) }\end{array}$ & $\begin{array}{l}\text { Dr Le Sy Viet, Tran The } \\
\text { Phuong, and staff }\end{array}$ \\
\hline $\begin{array}{l}\text { Hanoi, } \\
27 \text { February }\end{array}$ & $\begin{array}{l}\text { Forest Research Centre (FRC), } \\
\text { Phu Ninh, Phu Tho }\end{array}$ & Dr Ha Van Huy \\
\hline \multirow[t]{2}{*}{$\begin{array}{l}\text { Hanoi, } \\
28 \text { February }\end{array}$} & $\begin{array}{l}\text { Department of Forestry, } \\
\text { Ministry of Agriculture and } \\
\text { Rural Development }\end{array}$ & $\begin{array}{l}\text { Dr Pham Duc Tuan, Vu Thank } \\
\text { Nam }\end{array}$ \\
\hline & $\begin{array}{l}\text { Environmental } \\
\text { Agency }\end{array}$ & Bui Hoa Binh, Ho Kien Trung \\
\hline
\end{tabular}

